
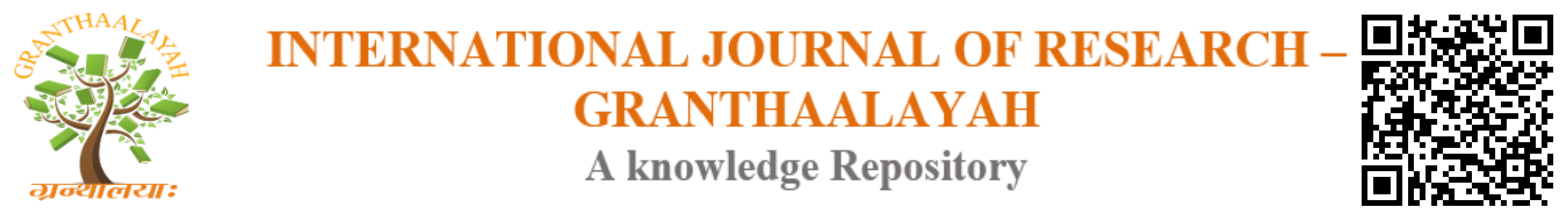

Social

\title{
THE IMPACT OF NOISE POLLUTION PHENOMENON IN THE CITIES OF BRAZZAVILLE AND POINTE-NOIRE IN THE REPUBLIC OF CONGO
}

\author{
Ngomah Le Temps Décide Amour Prestige *1, Ndeko Gertrude ${ }^{2}$, Ngomah Madgil Don \\ Stenay Junior ${ }^{3}$, Ngomah Le Temps Ondongo Nielenga Marichelle ${ }^{4}$, Diallo Akessi \\ Dzenabou Soraya $^{5}$, Nguema Ndong Alain Junior ${ }^{6}$, Dibiongo Hugues Vianney ${ }^{7}$ \\ 1, 2,7 School of Sociology of Environment (ELLIC), Marien Ngouabi University, Brazzaville, \\ Congo \\ ${ }^{3}$ School of Management, Wuhan University of Technology, Wuhan, Hubeil, China \\ ${ }^{4}$ School of Social Communication, Saint-Paul University, Ottawa, Ontario, Canada \\ ${ }^{5}$ School of Resources and Environmental Engineering, Wuhan University of Technology, \\ Wuhan, China \\ ${ }^{6}$ School of Civil Engineering and Architecture, Wuhan University of Technology, Wuhan
}

\begin{abstract}
The noise constitutes for the human beings with notched joints the world one of the nuisances most strongly felt. Apart from its importance for quality of life, the noise has also repercussions proven on health. Many countries strive to set up laws going with a view to fight against these nuisances which constitute an obstacle, an obstruction with quietude, the peace and the freedom of the populations. Congo Brazzaville is one of the countries of the world affected considerably by this phenomenon. Thus, this document treats primarily the causes and the consequences of the noises with Congo Brazzaville. This article Works out also some strategies which could contribute right now to fight against this phenomenon.
\end{abstract}

Keywords: Noise Pollution Phenomenon; Impact; Republic of Congo.

Cite This Article: Ngomah Le Temps Décide Amour Prestige, Ndeko Gertrude, Ngomah Madgil Don Stenay Junior, Ngomah Le Temps Ondongo Nielenga Marichelle, Diallo Akessi Dzenabou Soraya, Nguema Ndong Alain Junior, and Dibiongo Hugues Vianney. (2019). "THE IMPACT OF NOISE POLLUTION PHENOMENON IN THE CITIES OF BRAZZAVILLE AND POINTENOIRE IN THE REPUBLIC OF CONGO.” International Journal of Research - Granthaalayah, 7(2), 187-196. https://doi.org/10.29121/granthaalayah.v7.i2.2019.1023.

\section{Introduction}

The concept of noise pollution generally includes noise caused by various sources, the consequences of which may range from a transient but repeated gene to serious repercussions on the health, quality of life and/or in the functioning of ecosystems. Noise is the first source of 
complaints and one of the first sources of conflict, at work, between neighbors, between communities and users (Baudot J.C., 1998) [4]. From close ultrasound to infrasound, a wide range of wavelengths can be a source of stress or pathological consequences, depending on the intensity, duration of exposure and sensitivity of the exposed person or animal.

A large part of the world's urban population is confronted with noise pollution, and in particular those living near to roads, railways, airports, ports and certain factories or areas of activity. The neighbors of discotheques, busy crossroads are also confronted to that problem. Noise is one of the leading causes of individual complaints in many countries. Several large associations have formed in some countries around the world to fight against sound levels deemed unbearable. The fight against noise pollution is today a hot topic that haunts and mobilizes many organizations around the world. Our study therefore presents a particular interest. In approaching this subject, we wanted to understand in general how noise pollution is perceived in the Republic of Congo the main objective is:

- Evaluate the impact of noise pollution on the Congolese environment

This is accompanied by two specific objectives: the first is to identify the causes of noise pollution, and measure their impact on the health of the Congolese population; the second is to examine the regulation, its application and to study strategies likely to fight against noise nuisance in Congo Brazzaville. Indeed, several writings have been developed around the world on noise pollution. However, this theme is not often discussed in Congo Brazzaville; which, without a doubt, impoverishes our review of the literature in the specific context of our study (the Congo). Indeed, it must be said that noise pollution is characterized by a high level of noise to the point of having adverse consequences on human health. Noise pollution can affect health and quality of life, with physical and/or psychological consequences for the men and women who suffer from it, and also affect biodiversity.

According to (WHO, 2003) [11], any country governed by the rule of law is supposed to ensure the tranquility of its population at all levels, by combating the social phenomena that constitute a barrier to freedom, a threat to the good health of its citizens. As early as 1948, it already affirmed that "health is not only the absence of disease, but a state of complete physical, mental and social well-being". If we consider that noise does not achieve a complete state of physical, mental and social well-being, then this nuisance goes beyond the social phenomenon and its quality of life issue to become a health issue. This reflection suggests that noise pollution is a direct attack on personality, an assumption strongly supported by (BERI J.C, 2011), (Caballero Francis, 1981 and Guillaume Le Nost 2007). [5, 6, 7]

(UNDP, 2001) [12], reports that noise has harmful effects on human health: stress, sleep disorders, effects on the cardiovascular, immune and endocrine system, and consequences for mental health.

(Unicef, 2004) [13], points out that noise is much more than a nuisance. It is also very often a real aggression against health. At least 2 out of 5 children are affected by noise when they are born.

According to (AFSSET, 2004) [1]: A study of 4391 people living in Ile-de-France, taking medication against hypertension is 5.6 times more common among men aged 40 to 69 whose home are overflown by planes. Anxiety and antidepressants are increased 10-fold in women aged 40 to 
69 living in a very noisy place. For women aged 15 to 39 whose homes are overflown by planes, the frequency of hospitalization is 5 times greater than normal. Noise pollution can have very harmful impacts on hearing, and can lead in the most severe cases to deafness.

According to a study leading by (INSEE, 2002), quoted by (Martin-Houssart G., Rizk C.,) [10] shows that $54 \%$ of respondents say they are annoyed by the noise when they are at home, $28 \%$ are often and $26 \%$ are distracted some time. Transport is the first source of annoying noise. "More than a third of urban households living near a busy street, a railway or airport say they are often bothered by noise," explain INSEE.

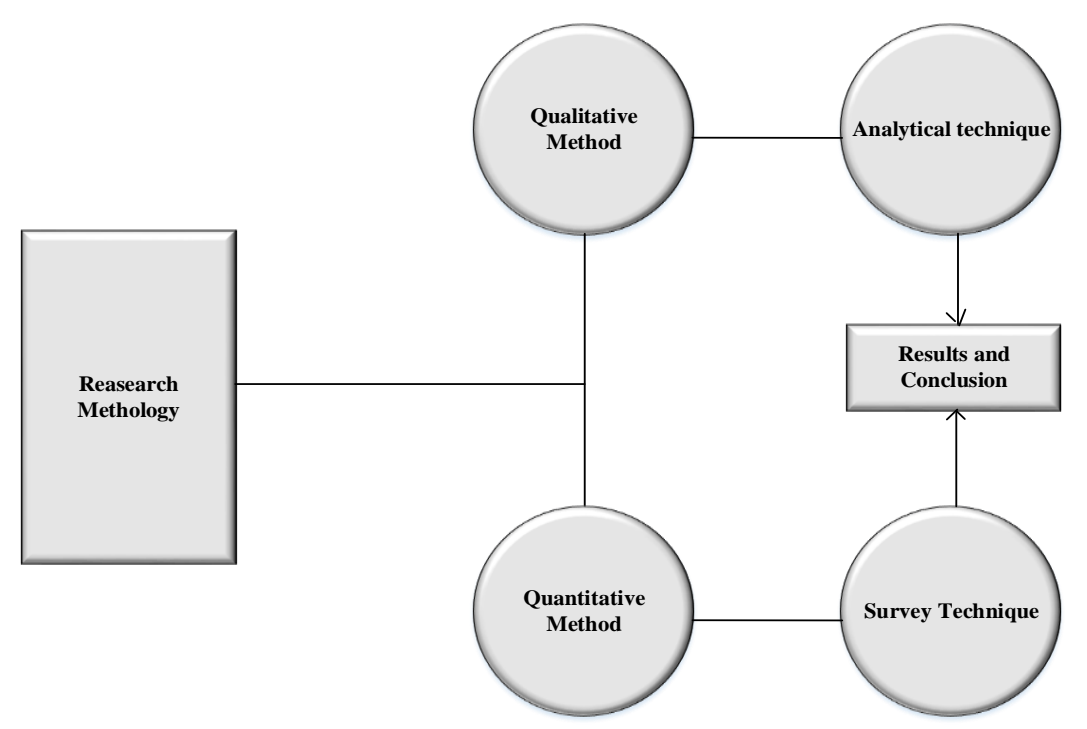

Figure 1: Research Methodology

To carry out our study, we used the following methods: the analytical technique, according to the observations. Indeed, we have observed the Congolese environment, and analyzed some documents such as (books, journals, theses, memoirs, reports, archives, scientific articles and many other documents that deal directly or indirectly with the issues of noise pollution). We followed through the radio, television and the internet on the issue of noise pollution. It must be said that this technique allowed us to make in-depth analyzes in order to achieve the objectives of our research. As for the investigation technique, it served as a real investigative tool. It allowed us to have true data on the opinions of the public exposed to this phenomenon (Sound pollution).

\section{Main causes of Noise}

Noise is one of the major nuisances of everyday life. Noise pollution is omnipresent, especially in urban areas. The causes of noise pollution are many [2], [3]. We cannot cite all of them here, but will present just a sample of the activities that are behind them. It should be noted that this list is not exhaustive. In Most cases, the noise comes from:

- Road transport (approved mobile mechanical sources: automobiles, horns, trucks, maneuvers);

- Rail transport (trains ...);

- Air transport (Air traffic and airports); 
- Neighborhood noises (Neighborhood: loud music on board public transit, screaming, nuisance alarms, fireworks); Hugel F, [9]

- Various professional and domestic appliances (lawnmowers, jackhammers ...);

- Nocturnal troubles (drinking establishments, churches "night of prayer, preaching, music with high-performance instruments, morning bell rattles", mortuary vigils)

- Point mechanical sources (machinery, factories, generators);

- punctual or sustainable works and sites;

- Animal sources (barking);

\section{Congolese Legal and Regulatory Framework on Noise Pollution}

We will quote and explain the laws and even the regulations on noise pollution that have been put in place by the Congolese authorities.

It must be remembered that regulations are all the requirements, standards and legal obligations that must be complied with (*). In this sense, it is one of the essential determinants of ensuring the smooth running of activities in all sectors of human society; and aims to preserve the environment as a whole against all evils.

In the Congo, it is the application of Decree No. 55-57 of May 20, 1955, which regulates drinking establishments, and sets up the well-defined instructions to be followed by these establishments. This decree is reinforced by Order No. 4086 / MINTT / SGAT / DEC / SAG of August 23, 1979, fixing the days and opening hours of dance halls and night clubs throughout the territory of the Republic of Congo. (*) However, Law No. 003/91 of 23 April 1991 on the protection of the environment stipulates in its $11^{\text {th }}$ title:

- Any noise causing discomfort to the neighborhood or harmful to the health of the man is forbidden. (Article 60)

- No property, dwelling or their dependencies, excessive noise from phonographs, tape recorders, radio and television equipment, loudspeakers, musical instruments, fireworks, firecrackers, firearms, industrial, commercial or household work are forbidden unless authorized by the competent authority. (Article 61)

$>$ Noise under any circumstances are not allowed:

$>$ warning devices with hoarse and strident sounds of motor vehicles;

$>$ vehicle engines without an effective silencer;

$>$ whistles, sirens and noisy devices;

$>$ Night fires. (Article 62)

This prohibition does not apply to ambulances and police vehicles when necessary.

- Parades and fairground music are forbidden unless expressly authorized by the competent authority. (Article 63);

- Occupants or facility owners must maintain noise level at a tolerable level. To this end, they must take measures to isolate noisy workshops, to insulate the premises or to use techniques or any other appropriate means to achieve this (Article 64);

- An order issued by the Minister for the Environment under this law establishes the noise standards (Article 65). 
In short, all of this regulation has three aims, including: the preservation of public order, health and morality;

\section{Investigation into the cases of noise nuisances in Congo Brazzaville}

Congo Brazzaville and other countries around the world suffer from a great deal of noise pollution. This, attracts more than one researcher to plunge their reflection on this company. This is the case for us today. Indeed, during our investigation, we identified several specific cases on the noise pollution. Thus, we found that in front of hospitals, school and academic circles and some places, noise is greatly resonated and affects the health of many people on a daily basis.

- Result of the Investigation

The table below describes the results of our survey. These data allowed us to make an analysis of noise environment in Congo.

Table 1 : Survey data

\begin{tabular}{|c|c|c|c|}
\hline Cities & Districts & $\begin{array}{l}\text { Sources of noise } \\
\text { pollution }\end{array}$ & Consequences on population \\
\hline \multirow[t]{2}{*}{ Brazzaville } & $\begin{array}{l}\text { Moungali (zone: } \\
\text { between Moungali } \\
\text { market and Poto- } \\
\text { poto market) }\end{array}$ & $\begin{array}{l}\text { - } 142 \text { drinking } \\
\text { establishments } \\
\text { have been } \\
\text { identified. } \\
\text { - } 90 \text { churches have } \\
\text { been identified }\end{array}$ & \multirow{4}{*}{$\begin{array}{l}\text { For the two sources of noise } \\
\text { mentioned as an example, } 94 \% \text { of } \\
\text { people are affected by them, and } \\
\text { even want the closure of some of } \\
\text { these establishments. } \\
\text { We note the deterioration of the } \\
\text { social climate, conflicts between } \\
\text { residents of the same neighborhood. } \\
\text { In short, it must be said that it has } \\
\text { health, social and economic } \\
\text { consequences. }\end{array}$} \\
\hline & $\begin{array}{l}\text { Bacongo (zone: } \\
\text { behind the Total } \\
\text { market, towards } \\
\text { the UMNG }\end{array}$ & $\begin{array}{l}\text { - } 199 \text { drinking } \\
\text { establishments } \\
\text { have been } \\
\text { identified. } \\
\text { - } 129 \text { churches } \\
\text { have been } \\
\text { identified }\end{array}$ & \\
\hline \multirow[t]{2}{*}{$\begin{array}{l}\text { Pointe- } \\
\text { Noire }\end{array}$} & $\begin{array}{l}\text { Nkouikou (from } \\
\text { Rebecca through } \\
\text { Vonvon until } \\
\text { August } 15 \text { and II } \\
\text { Poteaux) }\end{array}$ & $\begin{array}{l}-290 \text { drinking } \\
\text { establishments } \\
\text { have been } \\
\text { identified. } \\
\text { - } 191 \text { churches } \\
\text { have been } \\
\text { identified }\end{array}$ & \\
\hline & $\begin{array}{l}\text { Tsé-tsé and Fond } \\
\text { Tsé-tsé }\end{array}$ & $\begin{array}{l}\text { - } 370 \text { drinking } \\
\text { establishments } \\
\text { have been } \\
\text { identified. } \\
\text { - } 206 \text { churches } \\
\text { have been } \\
\text { identified }\end{array}$ & \\
\hline
\end{tabular}

Source: By author (survey). 


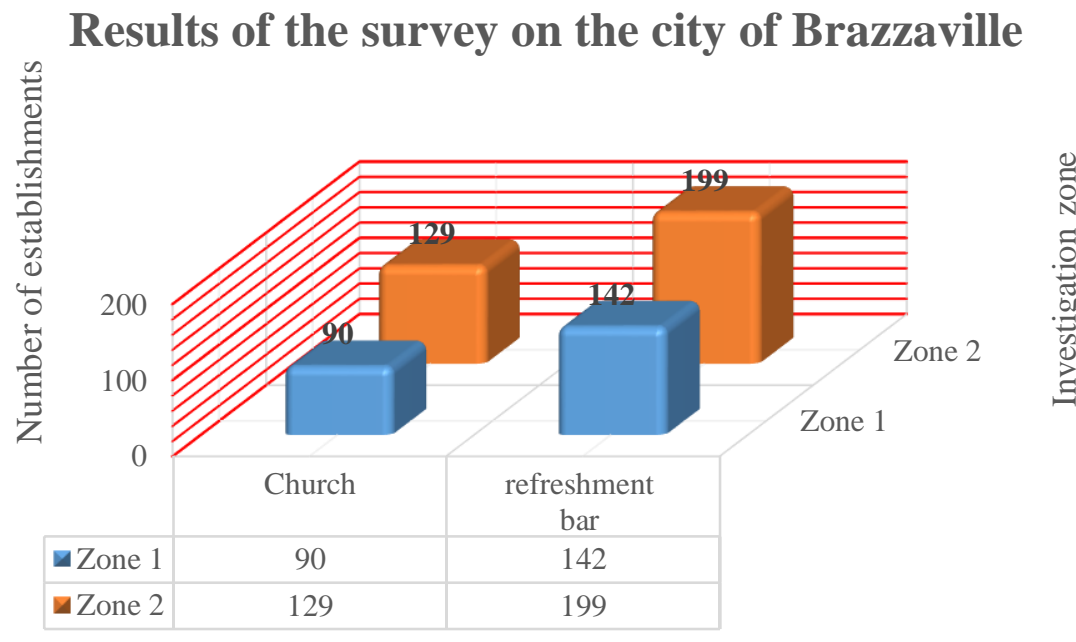

-Zone 1 ZZone 2

Figure 2: Results of the survey on the city of Brazzaville

\section{Results of the survey on the city of Pointe-Noire}

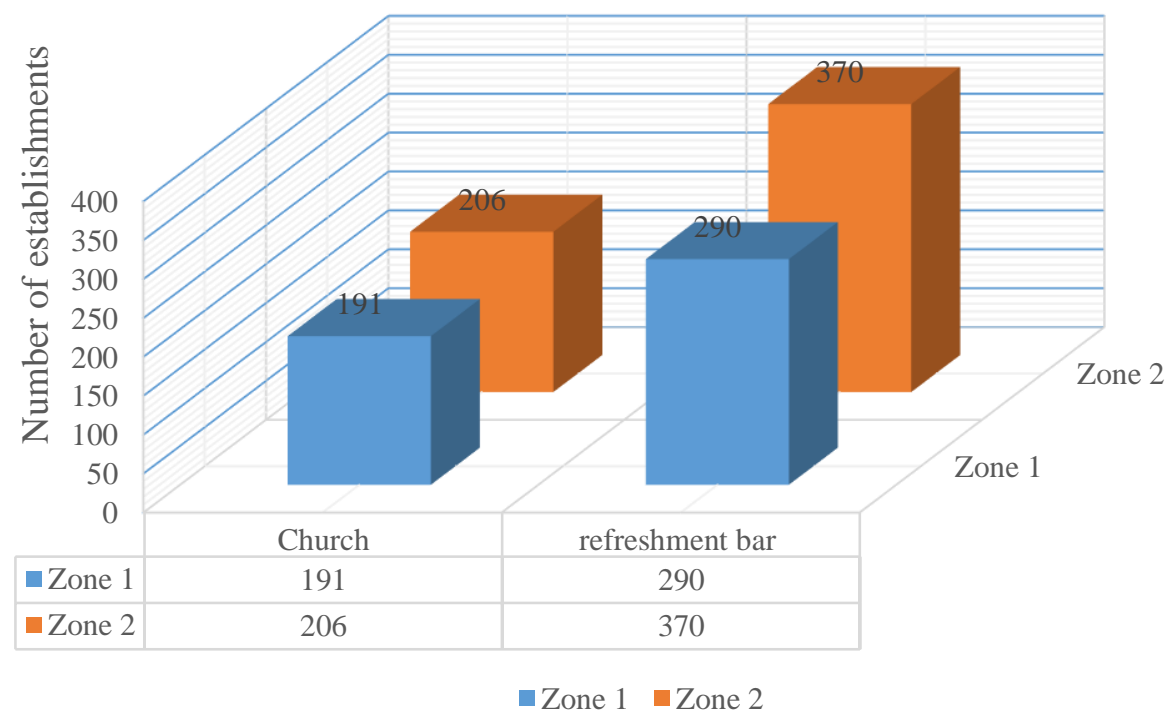

0
0
0
0
0
0
0
0
0
0
0
0
0

Figure 3: Results of the survey on the city of Pointe-Noire

This table and these figures are the result of our survey. Although we cannot give in this article all the possible details of our survey, he nevertheless agreed to present in a synoptic way the most essential data (see table). Taking as an example the four districts where we surveyed, we can see that the phenomenon of noise pollution is increasing day by day; and affects the largest number of Congolese people. In these four districts of two capitals of the Republic of Congo alone, there are 
1001 pubs and 616 churches, representing 90\% of the establishments likely to produce noise pollution. It should also be noted that these establishments operate freely and even exaggeratedly without taking into account the laws in force and the population affected by nuisances.

During our investigation, several people confided in us to explain the direct consequences they face, and to denounce the anarchy that reigns in Congo. All this is due to the failure to take into account the requests submitted by the population to the competent authorities; but also because of the impunity that is running rampant.

\section{Consequences of Noise Pollution on the Congolese Population}

In summary, it should be said that this table presents considerable figures (data) that sufficiently explain how the Congolese population suffers from the lack of peace, freedom and quiet due to certain activities, factors that cause noise pollution; and how regulatory laws are violated by a category of people. This exponential increase in the number of establishments causing noise pollution obstructs the freedom of many citizens living in the two capitals of Congo. These data should be used by the competent Congolese authorities to take acerbic measures to regulate the exercise of the activities of these establishments.

In addition to the factors (causes) mentioned above in our table, elements of our survey on Brazzaville and Pointe-Noire, it is also worth mentioning some specific events that cause several repercussions on public health and the social climate between populations. The events of March 4, 2012 are a tangible example of the above-mentioned repercussions: (The strong detonations of the explosions of the "Mpila" armored regiment caused psychological sequelae, disruptions to the hearing systems of almost all the victims of this tragedy. Out of $100 \%$ of people presented to the $\mathrm{CHU}$, living in districts greatly devastated by this tragedy, at least $90 \%$ of them suffer from serious health and behavior problems caused by the sound of explosions. (This can be hearing problems, nervous tensions...) [7] (*).

Source : Our Survey

Table 2: Public opinion

\begin{tabular}{|l|l|}
\hline & Respondents Interviewed \\
\hline Yes & 2901 \\
\hline No & 99 \\
\hline Total & 3000 \\
\hline
\end{tabular}

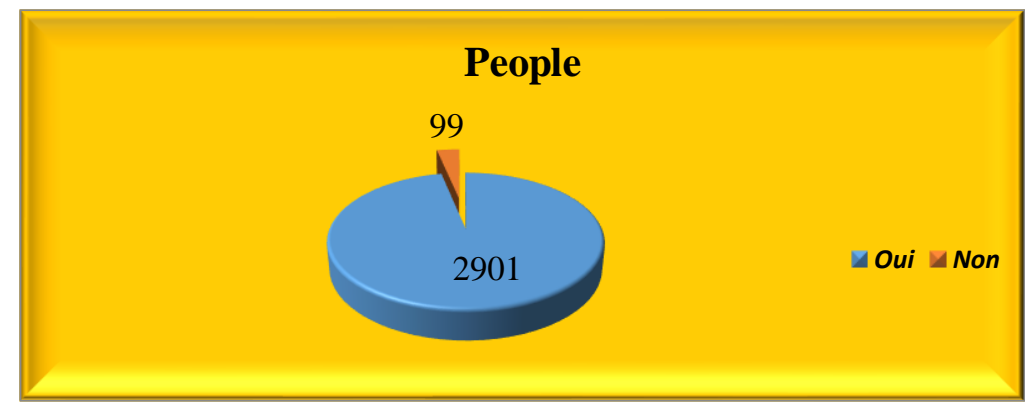

Figure 4: Public opinion

Source: Our Survey 
The table and graph above give the position or response of the respondents on the consequences of noise pollution. Out of 3000 people interviewed, 2901 are bothered by noise pollution. They are directly affected by the effects or even the repercussions of N.S. (The "Yes in blue" item expresses all the victims of noise pollution, and the "No in red" item shows all the people who believe that they are not at all victims of noise pollution, and that they are indeed normal for the balance of life in society).

Indeed, it must be deduced that every year that passes, the phenomenon continues to grow in Congo. Because it is reflected both in a finding and in complaints from victims filed with the municipal authorities. Thus, the following data:

Table 3 Complaints filed with town halls

Sources: Town halls and Author.

\begin{tabular}{l|l}
\hline Years & Complaints \\
\hline 2008 & 425 \\
\hline 2009 & 590 \\
\hline 2010 & 393 \\
\hline 2011 & 540 \\
\hline 2012 & 575 \\
\hline 2013 & 350 \\
\hline Total & 2873 \\
\hline
\end{tabular}

Hospital sources (Brazzaville University Hospital Center)

\section{Complaints filed with town halls}

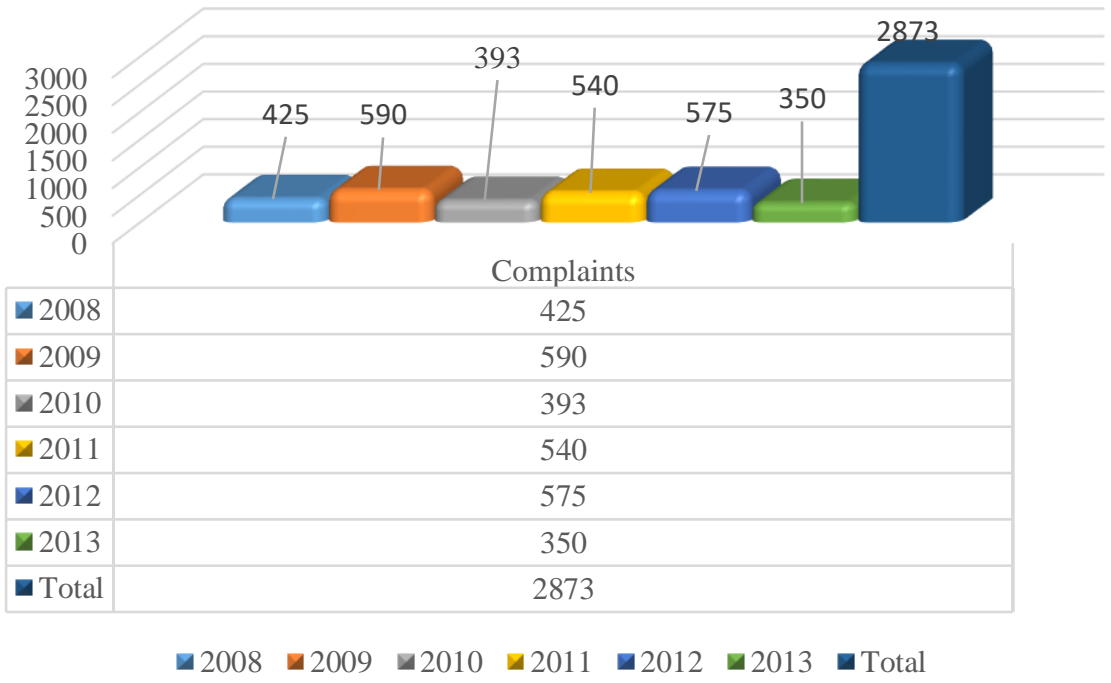

Sources: Town halls and Author

Figure 3: Complaints filed with town halls

The above-mentioned table and graph reflect the level of discomfort that noise pollution causes to the Congolese population. Every year, the number of complaints filed with town halls continues to increase. From 2008 to the present, approximately 2873 complaints have been filed by victims 
of noise pollution in the areas where we have investigated. This explains why this phenomenon is a spectacular daily phenomenon. The government will therefore have to put in place strategies and even policies to combat this phenomenon. Thus, in the following lines, we will put in place some suggestions to combat this phenomenon.

\section{Prospects for the Future}

- To combat noise pollution, the Congolese authorities should take measures aimed at:

- Acoustic insulation of dwellings subject to excessive noise;

- Improving the daily noise control system, particularly in terms of repression, awareness and regulation;

- The development of noise mapping.

- The mayors of Brazzaville and Pointe-Noire must also regulate the organization of funeral wakes, which are also a source of noise pollution. It is undeniable that the loss of a family member is a painful time, but it should not be an opportunity for the neighborhood to be subjected to noise pollution for five days or a week.

- Mayors must also regulate funeral processions because the sirens of hearses and horns of accompanying vehicles are experienced daily as noise nuisances.

- Regulate road traffic with vehicles often lacking all technical controls, bars and "Ngandas" broadcasting music at an uncontrolled volume, street vendors at an auction thus disturbing the tranquility of city dwellers, and businesses whose music broadcasting resembles more a permanent concert of traumatic sounds that is the most recurrent cause of complaints from the populations of Brazzaville and Pointe-Noire.

Nor is it about depriving the Congolese of certain distractions inherent even in our culture and society. On the contrary, it is a question here of proposing a favorable alternative to regulate this pollution. Municipal officials have a duty to ensure that this noise pollution does not spread. This is a significant source of environmental degradation in the same way as degradation through the spread of waste. In an acoustically high environment, people are intolerant and sometimes subject to severe aggressive impulses. Often the citizen has no other means than to act himself by calling on the owners of the so-called noisy places. These situations lead to neighborhood conflicts and extreme tensions.

It so happens that this municipal failure can be resolved through coherent measures and in compliance with the law. That is why we also suggest that emergency measures to alleviate the suffering of city dwellers should be initiated:

- Adopt a municipal decree regulating noise pollution (60 decibels on average during the day and 50 at night);

- Elaborate a charter of good sound neighborliness and a charter of night life;

- Prohibit noisy vehicles without a statutory roadworthiness test;

- Regulate open outcry sales in residential areas;

- Prohibit the uncontrolled expansion of markets in residential areas;

- Impose a dissuasive fine for businesses that use noise without authorization;

- Above all, authorities should ensure that laws are respected and strictly applied without distinction of person or place. For good communication, these laws or the decisions taken 
should be published in the official gazette, thus allowing the population to be informed of them (prohibitions and sanctions, etc.)

\section{Conclusion}

In this article, we have shown the existence and expansion of noise pollution in Congo Brazzaville. The latter, which have now become a daily phenomenon, constitute a permanent threat to the good health of Congolese citizens. Indeed, the fight against this phenomenon through the application of existing texts would constitute a step towards good governance. Noise pollution is undoubtedly a crucial public health problem affecting the quality of life. Their impact on health is becoming an economic issue. The results of our study suggest that the phenomenon of noise pollution has reached its peak in Congo Brazzaville. In four districts of the two capital cities alone, there are about 1001 pubs, 606 churches, or $90 \%$ of establishments likely to produce noise pollution. Although we did not mention it in our dashboard, the PK, Mfilou, Makazou districts are flown over by at least 60 aircraft per day (air traffic). As many of the causes of noise pollution as we cannot mention them all here and now. Let us just remember that Congo Brazzaville has undeniably become a real field of noise pollution. The statistical figures mentioned above are irrefutable proof of this. For only six years, more than 2873 complaints were filed, dealing with "Noise pollution". This will require public authorities to take immediate decisions to combat this phenomenon.

\section{References}

[1] AFSSE, Impacts sanitaires du bruit - État des lieux Indicateurs bruit-sante - Ed. Agence française de sécurité sanitaire environnementale, Maisons-Alfort, 2004, 304 p.

[2] Association des Maires de Grandes Villes et CIDB, Les Nuisances sonores dans les grandes villes et agglomération, Etude n¹97, 2003, 49 p.

[3] Association des Maires de Grandes Villes et CIDB, Cartes du bruit et des plans de prévention du bruit dans les grandes agglomérations, Etude ${ }^{\circ} 218,2007$

[4] BAUDOT J.C., les sons, les bruits de la ville au-delà des nuisances sonores, 1998,

[5] BERI J.C, Brazzaville et Pointe-Noire au bord de l'implosion sonore, Ed. Dac presse, 2011, 11p

[6] Caballero Francis, essai sur la notion de nuisance, préface de Jean Rivero, thèse, paris, LGDI, 1981.

[7] CHU Congo Brazzaville, Rapport annuel, 2012

[8] Guillaume LE NOST, Contribution à l'étude de l'impact environnemental sonore des sites industriels : une typologie perceptive des sources de bruit, thèse, paris, 2007, 247p

[9] Hugel F, Les Bruits de voisinage et les communes, prise en charge, difficultés et propositions d'actions, Rapport au Ministre de l'Aménagement du Territoire, mai 2000, 233 p.

[10] Martin-Houssart G., Rizk C., Mesurer la qualité de vie dans les grandes agglomérations, Insee Première $n^{\circ} 868$, INSEE, 2002

[11] OMS, Résumé d'orientation des Directives relatives au bruit dans l'environnement, OMS, 2003, $25 \mathrm{p}$

[12] PNUD, 2001, Rapport sur Le Développement Humain

[13] Unicef, 2004, La Situation des enfants dans le Monde

\footnotetext{
*Corresponding author.

E-mail address: letempsdecide@ gmail.com, gertrudnek@ yahoo.fr, juniorngomah@ gmail.com, ounievh@gmail.com, akessisoraya@gmail.com, alain_junior004@yahoo.fr, huguenney@yahoo.fr
} 